\title{
Deteksi Bakteri pada Ibu Hamil dan Post Partum di Kabupaten Mamuju
}

\author{
Ashriady \\ Jurusan Kebidanan, Poltekkes Kemenkes Mamuju; ashriady.abumuadz@gmail.com (koresponden) \\ Abbas Mahmud \\ Jurusan Kebidanan, Politeknik Kesehatan Kementerian Kesehatan Mamuju; abbas.mahmud11@ gmail.com \\ Nurdiana \\ Jurusan Kebidanan, Politeknik Kesehatan Kementerian Kesehatan Mamuju; nurdiana.sst76@gmail.com
}

\begin{abstract}
Causes of non-obstetric sepsis in pregnant women include malaria, HIV and pneumonia. Urinary tract infections are often linked as the most common cause of infection in pregnancy. Common causes of sepsis are gram-negative bacteria such as Acinetobacter calcoaceticus, Enterobacter aerogenes, Pseudomonas sp and Eschericia coli. High risk for pregnant women is a condition of deviation from normal which directly causes morbidity and death of both mother and baby breech location in premigravida, severe infection/sepsis, preterm labor. Based on this description, researchers were interested in screening bacteria in pregnant women with sepsis in Mamuju Regency in West Sulawesi Province. The purpose of this study was to detect the presence of bacteria in pregnant women in Mamuju Regency. This type of research is descriptive observational research. The time of the study is in the months of May to November 2019. The population was all pregnant women who visit the PKM and/or Hospital in Mamuju Regency, taken using the accidental Sampling method. The results showed a bacterial infection with gram-negative (rod) and gram-positive (round) types in pregnant women. Early detection of the incidence of infection and the cause of the infection is still needed so the researchers recommend that early screening be done on pregnant women. This research can be continued with various specimens such as sputum or wound swabs in women with caesarean section.
\end{abstract}

Keywords: pregnant women; infections; bacteria; gram negative

\begin{abstract}
ABSTRAK
Penyebab sepsis non obstetrik pada wanita hamil diantaranya malaria, HIV dan pneumonia. Infeksi saluran kemih sering dikaitkan sebagai penyebab infeksi tersering pada kehamilan. Penyebab sepsis pada umumnya adalah bakteri gram negatif seperti Acinetobacter calcoaceticus, Enterobacter aerogenes, Pseudomonas sp dan Eschericia coli. Risiko tinggi pada ibu hamil adalah keadaan penyimpangan dari normal yang secara langsung menyebabkan kesakitan dan kematian ibu maupun bayi letak sungsang pada pramigravida, infeksi berat/sepsis, persalinan prematur. Berdasarkan uraian tersebut maka peneliti tertarik untuk skrining bakteri pada ibu hamil penderita sepsis di Kabupaten Mamuju di Provinsi Sulawesi Barat. Tujuan penelitian untuk mendeteksi keberadaan bakteri pada ibu hamil di Kabupaten Mamuju. Jenis penelitian adalah penelitian observasional deskriptif. Waktu penelitian pada Bulan pada bulan Mei sampai November 2019. Populasi adalah seluruh Ibu hamil yang berkunjung ke PKM dan atau Rumah Sakit di Kabupaten Mamuju, diambil dengan metode Accidental Sampling. Hasil penelitian menunjukkan ditemukan infeksi bakteri dengan jenis gram negatif (batang) dan gram positif (bulat) pada ibu hamil. Deteksi awal terhadap kejadian infeksi dan penyebab infeksi tersebut tetap diperlukan sehingga peneliti menyarankan untuk dilakukan screening awal pada ibu hamil. Penelitian ini dapat dilanjutkan dengan berbagai specimen seperti sputum maupun swab luka pada ibu yang mengalami Caesar.
\end{abstract}

Kata kunci: ibu hamil; infeksi; bakteri; gram negatif

\section{PENDAHULUAN}

Infeksi sering memperparah kondisi penyakit, sepsis umumnya menjadi jalan terakhir menuju kematian baik dari penyakit menular dan tidak menular di seluruh dunia. Jika sepsis berkembang selama kehamilan, saat atau setelah melahirkan, atau setelah aborsi, itu disebut sepsis ibu. Meskipun sangat dapat dicegah, sepsis ibu terus menjadi penyebab utama kematian dan morbiditas untuk wanita hamil atau yang baru hamil ${ }^{(1)}$.

Kejadian sepsis pada wanita hamil dihubungkan dengan komplikasi infeksi seperti infeksi saluran kemih, korioamnionitis, endometritis, luka infeksi dan abortus septik. Penyebab sepsis non obstetrik pada wanita hamil diantaranya malaria, HIV dan pneumonia. Infeksi saluran kemih sering dikaitkan sebagai penyebab infeksi tersering pada kehamilan. Hal ini dikarenakan terjadinya perubahan secara anatomi dan fisiologis sehingga memudahkan ascending infection. Perubahan kimiawi urine juga memudahkan pertumbuhan kuman patogen sebagai penyebab infeksi ${ }^{(3)}$.

Penyebab sepsis pada umumnya adalah bakteri gram negatif seperti Acinetobacter calcoaceticus, Enterobacter aerogenes, Pseudomonas sp dan Eschericia coli. Sepsis awitan dini pada sebuah penelitian 
menunjukkan bahwa terbanyak disebabkan oleh bakteri gram negatif (80,5\%) sedangkan pada sepsis awitan lambat ditemukan bakteri gram positif dan negatif dalam jumlah yang hampir sama. Dua subjek dengan kultur darah Candida tropicalis dan sel ragi ditemukan pada sepsis awitan lambat ${ }^{(4)}$.

Risiko tinggi pada ibu hamil adalah keadaan penyimpangan dari normal yang secara langsung menyebabkan kesakitan dan kematian ibu maupun bayi letak sungsang pada pramigravida, infeksi berat/sepsis, persalinan prematur ${ }^{(2)}$. Berdasarkan uraian tersebut maka peneliti tertarik untuk skrining bakteri pada ibu hamil penderita sepsis di Kabupaten Mamuju di Provinsi Sulawesi Barat.

\section{METODE}

Jenis penelitian ini adalah penelitian observasional deskriptif dilaksanakan pada bulan Mei sampai November 2019. Penelitian ini dilakukan pada bulan Mei sampai November tahun 2019. Pengumpulan sampel dilakukan di Puskesmas dan Rumah Sakit di Kabupaten Mamuju. Pengujian sampel dilakukan di Laboratorium Mikrobiologi Politeknik Kesehatan Mamuju

Alat dan bahan penelitian adalah: Laminar air flow cabinet, autoklaf (Webeco $\mathrm{GmbH}$ ), inkubator, petri disk, erlenmeyer $250 \mathrm{ml}$ (pyrex), gelas ukur $50 \mathrm{ml}$ (pyrex), timbangan (Ohaus), gelas piala $400 \mathrm{ml}$, batang pengaduk, tabung reaksi, mikroskop (Olympus), Objek gelas, deck gelas, Ose, holder, Pemanas, tabung vakum.

Medium MacConkey (Oxoid CM0115), medium BHIB (Merck), normal saline, zat warna untuk pewarnaan gram, Nutrien agar, air suling steril, Spritus, Alkohol $70 \%$, Minyak Inersia, NaCL fisiologis, pepton, stik swab steril, larutan Iodium.

\section{Popolasi dan Sampel}

Populasi dalam penelitian ini adalah Ibu hamil atau Ibu post partum yang berkunjung ke PKM dan atau Rumah Sakit di Kabupaten Mamuju. Sampel penelitian adalah Ibu hamil atau ibu post partum yang bersedia diambil sampel darah atau urinenya di PKM dan Rumah Sakit di Kabupaten Mamuju, Sampel berupa darah atau urine ibu hamil diambil menggunakan tabung vakum atau pot urine sebanyak $10-20 \mathrm{ml}$.

Sampel dimasukkan ke dalam medium Brain Heart Infusion Broth (BHIB) dengan perbandingan (1:1) lalu diaduk dan dihomogenkan. Diinkubasi pada suhu $37^{\circ} \mathrm{C}$ selama 24 jam. Setelah itu untuk isolasi bakteri, diambil menggunakan ose steril kemudian ditanam pada medium MacConkey plat dan medium agar plat lalu diinkubasi selama 24 jam pada suhu $37^{\circ} \mathrm{C}$.

Koloni yang tumbuh pada medium MacConkey digunakan untuk pewarnaan Gram negative dan EMB agar untuk bakteri Gram positif. Isolat bakteri diambil dari medium MacConkey dan Medium EMB agar diamati bentuk dan warna koloni. Selanjutnya diambil biakan koloni tersebut lalu ditempatkan pada objek glas lalu dilakukan pewarnaan gram, selanjutnya diamati di bawah mikroskop pembesaran 1000x (Positif gram-negatif jika bakteri berwarna merah).

\section{HASIL}

\section{Karakteristik Responden}

Sampel darah atau urine diperoleh dari 44 orang responden, yang terdiri dari 38 orang ibu hamil dan 6 orang ibu post partum. Sampel diambil secara aksidental sampling pada unit pelayanan kesehatan di Kabupaten Mamuju. Sembilan sampel diambil dari RSUD Kabupaten Mamuju dengan menggunakan tenaga laboratorium yang terlatih dari RS tersebut sedangkan 35 sampel diambil di Wilayah Kerja Puskesmas Bambu, Binanga dan Rangas dengan mengunakan tenaga laboratorium terlatih dari Poltekkes Kemenkes Mamuju. Untuk lebih jelasnya, karakteristik sampel dapat dilihat pada tabel 1.

Tabel 1. Distribusi sampel deteksi bakteri pada ibu hamil dan post partum berdasarkan jenis spesimen, kelompok sampel, berat badan, tekanan darah, umur dan gravida di Kabupaten Mamuju tahun 2019

\begin{tabular}{|c|c|c|c|c|c|}
\hline Karakteristik & $\mathrm{n}$ & $\%$ & Karakteristik & $\mathrm{n}$ & $\%$ \\
\hline $\begin{array}{l}\text { Jenis Spesimen } \\
\text { a. Darah } \\
\text { b. Urine }\end{array}$ & $\begin{array}{l}10 \\
34\end{array}$ & $\begin{array}{l}22,7 \\
77,3\end{array}$ & $\begin{array}{l}\text { Kelompok Sampel } \\
\text { a. Ibu Post Partum } \\
\text { b. Ibu hamil }\end{array}$ & $\begin{array}{c}6 \\
38\end{array}$ & $\begin{array}{l}13,6 \\
86,4\end{array}$ \\
\hline $\begin{array}{c}\text { Berat Badan } \\
\text { a. } \quad \leq 50 \mathrm{Kg} \\
\text { b. }>50 \mathrm{Kg}\end{array}$ & $\begin{array}{l}21 \\
23 \\
\end{array}$ & $\begin{array}{l}47,7 \\
52,3\end{array}$ & $\begin{array}{l}\text { Tekanan Darah } \\
\text { a. Normal } \\
\text { b. Tidak Normal }\end{array}$ & $\begin{array}{c}36 \\
8 \\
\end{array}$ & $\begin{array}{l}81,8 \\
18,2 \\
\end{array}$ \\
\hline $\begin{array}{l}\text { Umur } \\
\text { a. }<20 \text { Tahun } \\
\text { b. } \quad 20-30 \text { Tahun } \\
\text { c. }>30 \text { Tahun }\end{array}$ & $\begin{array}{c}5 \\
32 \\
7\end{array}$ & $\begin{array}{l}11,4 \\
72,7 \\
15,9\end{array}$ & $\begin{array}{l}\text { Gravida } \\
\begin{aligned} \text { a. } 1 \\
\text { b. } 2 \\
\text { c. } 3-5\end{aligned}\end{array}$ & $\begin{array}{l}20 \\
14 \\
10\end{array}$ & $\begin{array}{l}45,5 \\
31,8 \\
22,7\end{array}$ \\
\hline Jumlah & 44 & 100 & Jumlah & 44 & 100 \\
\hline
\end{tabular}




\section{Identifikasi Bakteri pada Ibu Hamil dan Post Partum}

Sampel yang diperoleh dari Rumah Sakit dan puskesmas berupa darah yang diambil sebanyak $20 \mathrm{ml}$ atau urine 10-20 ml dari ibu hamil dan post partum. Sampel dimasukkan ke dalam medium Brain Heart Infusion Broth (BHIB) dengan perbandingan (1:1) lalu diaduk dan dihomogenkan. Diinkubasi pada suhu $37^{\circ} \mathrm{C}$ selama 24 jam. Setelah itu untuk isolasi bakteri, diambil menggunakan ose steril kemudian ditanam pada medium MacConkey plat dan medium agar plat lalu diinkubasi selama 24 jam pada suhu $37^{\circ} \mathrm{C}$. Berikut adalah data hasil pemeriksaan bakteri pada Ibu hamil dan Post Partum.
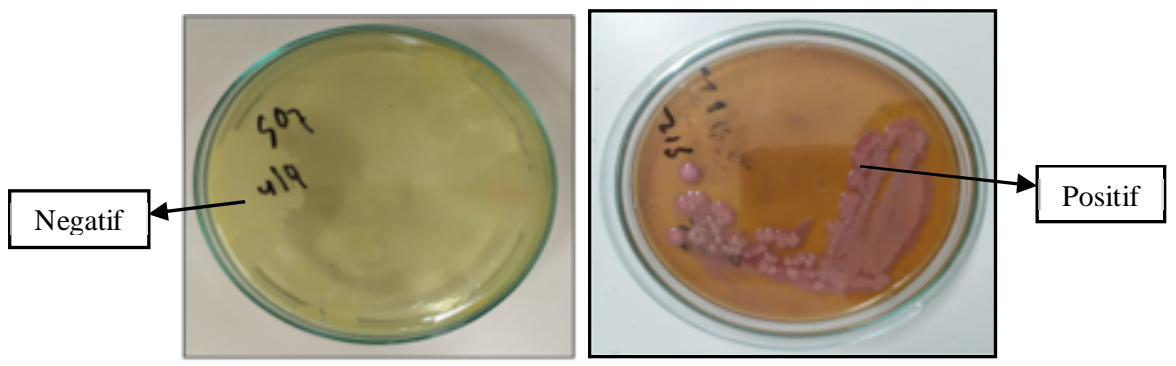

Gambar 1. Kultur media Nutrien Agar (NA) dan Mac Conkey (sumber: penelitian pribadi)

Tabel 2. Hasil pemeriksaan deteksi bakteri pada ibu hamil dan post partum di RSUD Kabupaten Mamuju

\begin{tabular}{|c|c|c|cc|c}
\hline \multirow{2}{*}{ Kode Sampel } & \multicolumn{2}{|c|}{ Kultur Media } & \multirow{2}{*}{ Kode Sampel } & \multicolumn{2}{c}{ Kultur Media } \\
\cline { 2 - 3 } & Nutrien Agar (NA) & Mac Conkey & & Nutrien Agar (NA) & Mac Conkey \\
\hline S01 & Negatif & Negatif & S23 & Positif & Positif \\
\hline S02 & Negatif & Negatif & S24 & Positif & Positif \\
\hline S03 & Negatif & Negatif & S25 & Positif & Positif \\
\hline S04 & Negatif & Negatif & S26 & Positif & Positif \\
\hline S05 & Negatif & Negatif & S27 & Positif & Positif \\
\hline S06 & Negatif & Negatif & S28 & Positif & Positif \\
\hline S07 & Negatif & Negatif & S29 & Positif & Positif \\
\hline S08 & Negatif & Negatif & S30 & Positif & Positif \\
\hline S09 & Negatif & Negatif & S31 & Positif & Positif \\
\hline S10 & Negatif & Negatif & S32 & Positif & Positif \\
\hline S11 & Positif & Positif & S33 & Positif & Positif \\
\hline S12 & Positif & Positif & S34 & Positif & Positif \\
\hline S13 & Positif & Positif & S35 & Positif & Positif \\
S14 & Positif & Positif & S36 & Positif & Positif \\
\hline S15 & Positif & Positif & S37 & Positif & Positif \\
\hline S16 & Positif & Positif & S38 & Positif & Positif \\
\hline S17 & Positif & Positif & S39 & Positif & Positif \\
\hline S18 & Positif & Positif & S40 & Positif & Positif \\
\hline S19 & Positif & Positif & S41 & Positif & Positif \\
\hline S20 & Positif & Positif & S42 & Positif & Positif \\
\hline S21 & Positif & Positif & S43 & Positif & Positif
\end{tabular}

Berdasarkan hasil pewarnaan dengan menggunakan Media Mac Conkey dari 34 isolat menunjukkan bahwa koloni secara mikroskopis berbentuk batang, lurus, tunggal atau membentuk rantai pendek. Untuk lebih jelasnya dapat dilihat pada gambar 2.

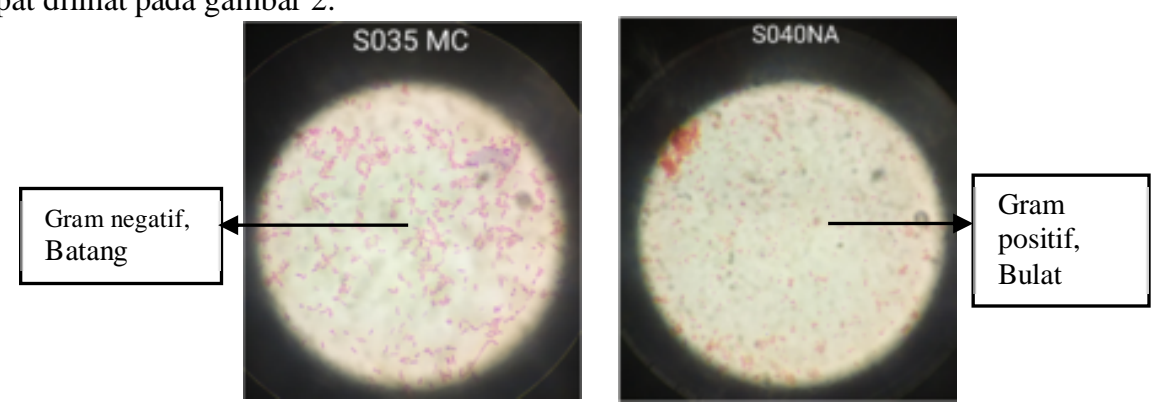

Gambar 2. Pemeriksaan mikroskopik media Nutrien Agar (NA) dan Mac Conkey (Sumber: penelitian pribadi) 
Tabel 3. Hasil pemeriksaan mikroskopik deteksi bakteri pada ibu hamil dan post partum di RSUD Kabupaten Mamuju

\begin{tabular}{|c|c|c|c|c|c|}
\hline \multirow{2}{*}{$\begin{array}{c}\text { Kode } \\
\text { Sampel }\end{array}$} & \multicolumn{2}{|c|}{ Pemeriksaan Mikroskopik } & \multirow{2}{*}{$\begin{array}{c}\text { Kode } \\
\text { Sampel }\end{array}$} & \multicolumn{2}{|c|}{ Pemetriksaan Mikroskopik } \\
\hline & Nutrien Agar (NA) & Mac Conkey & & Nutrien Agar (NA) & Mac Conkey \\
\hline S01 & - & - & S23 & Gram negatif, Batang & Gram negatif, Batang \\
\hline S02 & - & - & $\mathrm{S} 24$ & Gram negatif, Batang & Gram negatif, Batang \\
\hline S03 & - & - & $\mathrm{S} 25$ & Gram negatif, Batang & Gram negatif, Batang \\
\hline S04 & - & - & S26 & Gram negatif, Batang & Gram negatif, Batang \\
\hline S05 & - & - & S27 & Gram negatif, Batang & Gram negatif, Batang \\
\hline S06 & - & - & S28 & Gram negatif, Batang & Gram negatif, Batang \\
\hline S07 & - & - & S29 & Gram negatif, Batang & Gram negatif, Batang \\
\hline S08 & - & - & $\mathrm{S} 30$ & Gram negatif, Batang & Gram negatif, Batang \\
\hline S09 & - & - & S31 & Gram negatif, Batang & Gram negatif, Batang \\
\hline $\mathrm{S} 10$ & - & - & S32 & Gram negatif, Batang & Gram negatif, Batang \\
\hline S11 & Gram negatif, Batang & Gram negatif, Batang & S33 & Gram negatif, Batang & Gram negatif, Batang \\
\hline S12 & Gram negatif, Batang & Gram negatif, Batang & S34 & Gram negatif, Batang & Gram negatif, Batang \\
\hline S13 & Gram negatif, Batang & Gram negatif, Batang & S35 & Gram negatif, Batang & Gram negatif, Batang \\
\hline S14 & Gram negatif, Batang & Gram negatif, Batang & S36 & Gram negatif, Batang & Gram negatif, Batang \\
\hline S15 & Gram negatif, Batang & Gram negatif, Batang & S37 & Gram negatif, Batang & Gram negatif, Batang \\
\hline S16 & Gram negatif, Batang & Gram negatif, Batang & S38 & Gram negatif, Batang & Gram negatif, Batang \\
\hline S17 & Gram negatif, Batang & Gram negatif, Batang & S39 & Gram negatif, Batang & Gram negatif, Batang \\
\hline $\mathrm{S} 18$ & Gram negatif, Batang & Gram negatif, Batang & $\mathrm{S} 40$ & Gram negatif, Batang & $\begin{array}{c}\text { Gram negatif, Batang; } \\
\text { Gram positif, Bulat }\end{array}$ \\
\hline S19 & Gram negatif, Batang & Gram negatif, Batang & S41 & Gram negatif, Batang & Gram negatif, Batang \\
\hline $\mathrm{S} 20$ & Gram negatif, Batang & Gram negatif, Batang & S42 & Gram negatif, Batang & Gram negatif, Batang \\
\hline S21 & Gram negatif, Batang & Gram negatif, Batang & S43 & Gram negatif, Batang & Gram negatif, Batang \\
\hline S22 & Gram negatif, Batang & Gram negatif, Batang & S44 & Gram negatif, Batang & Gram negatif, Batang \\
\hline
\end{tabular}

\section{PEMBAHASAN}

Sepsis tetap menjadi penyebab utama morbiditas dan mortalitas $\mathrm{ibu}^{(5)}$. Sepsis menyumbang hingga $28 \%$ dari semua kematian $i b u^{(6)}$. Infeksi postpartum adalah penyebab utama kematian ibu di seluruh dunia. Sekitar lima juta kasus infeksi terkait kehamilan terjadi setiap tahun secara global, dan sekitar 75.000 mengakibatkan kematian $^{(7),(8)}$. Pengobatan ibu hamil sering tertunda karena adaptasi fisiologi kehamilan dan tanda/gejala yang tidak jelas atau tidak ada selama infeksi awal ${ }^{(5)}$. Oleh karena itu, informasi awal dapat membantu untuk mengidentifikasi ibu hamil yang berisiko.

Infeksi pneumonia/pernapasan dan infeksi saluran genital merupakan sumber sepsis yang paling umum. Infeksi yang paling umum pada wanita yang meninggal adalah pneumonia/infeksi pernapasan. Faktor-faktor risiko untuk morbiditas adalah usia yang lebih muda, kelahiran kehamilan multipel dan operasi Caesar ${ }^{(9)}$. saat ini, tidak ada alat yang valid untuk mengidentifikasi sepsis pada wanita hamil, dan alat yang digunakan pada populasi umum cenderung melebih-lebihkan mortalitas ${ }^{(6)}$.

Pada penelitian ini dilakukan deteksi bakteri pada ibu hamil. Deteksi bakteri menggunakan teknik kultur specimen darah atau urine ibu hamil dan atau ibu postpartum. Berdasarkan hasil pemeriksaan tersebut, terdapat infeksi bakteri pada ibu hamil dan ibu postpartum. Deteksi infeksi oleh bakteri pada ibu hamil atau post partum penting untuk penentuan penatalaksanaan sepsis pada kehamilan. Kunci penatalaksanaan adalah resusitas cairan dan terapi antimikroba yang tepat terhadap sumber infeksi dan melakukan tindakan pengendalian sumber yang tepat $^{(6)}$.

Pewarnaan gram yang dilakukan pada penelitian ini didasarkan pada perbedaan struktur dinding sel bakteri, sehingga menyebabkan perbedaan reaksi dalam permeabilitas zat warna dan penambahan larutan pencuci. Dinding sel bakteri Gram positif terdiri dari lapisan peptidoglikan yang tebal sedangkan dinding sel bakteri Gram negatif mempunyai kandungan lipid yang tebal. Ketika ditambahkan pewarnaan kristal violet maka dinding sel bakteri Gram positif maupun Gram negatif akan menyerap zat warna tersebut namun ketika diberi alkohol, kristal violet pada Gram negatif akan luntur disebabkan struktur dinding selnya yang sebagian besar tersususun oleh lipid, sehingga ketika diberi safranin (zat warna kedua) dinding sel bakteri gram negatif akan menyerapnya kembali sehingga hasil pewarnaan bakteri Gram negatif akan berwarna merah ${ }^{(10)}$.

Infeksi bakteri khususnya Infeksi postpartum yang paling umum termasuk endometritis (sepsis nifas), infeksi saluran kemih, infeksi di tempat bedah, infeksi aliran darah dan infeksi luka. Dalam sebuah studi sepsis nifas ditemukan $31 \%$ dapat menyebabkan kematian ibu. Satu-satunya faktor risiko terpenting untuk infeksi postpartum tampaknya adalah operasi caesar ${ }^{(8)}$. Sepsis dapat menimbulkan permasalahan pada kehamilan seperti timbulnya sepsis berat dan syok sepsis yang menyebabkan persalinan prematur, infeksi janin ${ }^{(11)}$. 
Bakteri Staphylococcus aureus (OS-MRSA) semakin banyak dilaporkan di seluruh dunia ${ }^{(7)}$. Berdasarkan penelitian Knowles et.al, 2015 bahwa Escherichia coli adalah patogen dominan, diikuti Grup B Streptococcus. Sepsis lebih sering terjadi pada wanita nulipara dan kelahiran kembar. Tujuh belas persen dari kejadian sepsis terjadi sebelum kelahiran, intrapartum 36\% dan postpartum $47 \%$. Sumber infeksi adalah saluran genital pada $61 \%$ pasien dan saluran kemih pada 25\%. Sepsis dikaitkan dengan kelahiran prematur dan tingkat kematian perinatal yang tinggi. Hampir $14 \%$ wanita membutuhkan perawatan tambahan. Organisme yang paling ganas adalah Streptococcus Grup A yang dikaitkan dengan sepsis postpartum saat aterm dan sepsis Escherichia coli prematur.

\section{KESIMPULAN}

Berdasarkan penelitian ini disimpulkan bahwa ditemukan infeksi bakteri dengan jenis gram negatif (batang) dan gram positif (bulat) pada ibu hamil di Kabupaten Mamuju.

Infeksi pada ibu hamil dan ibu post partum menjadi hal yang sangat penting untuk menjadi perhatian. Deteksi awal terhadap kejadian infeksi dan penyebab infeksi tersebut tetap diperlukan sehingga peneliti menyarankan untuk dilakukan screening awal pada ibu hamil. Penelitian ini dapat dilanjutkan dengan berbagai specimen seperti sputum maupun swab luka pada ibu yang mengalami Caesar.

\section{DAFTAR PUSTAKA}

1. WHO. Maternal sepsis [Internet]. Human Reproduction Programme. 2018 [cited 2018 Dec 3]. Available from: https://www.who.int/reproductivehealth/maternal-sepsis/en/.

2. Dinas Kesehatan Provinsi Sulawesi Barat. Profil Kesehatan Provinsi Sulawesi Barat Tahun 2014 [Internet]. 2015. Available from: www.depkes.go.id/resources/download/ profil/.../30_Sulawesi_Barat_2014. pdf\%0A\%0A.

3. Prayogo BW, Prasetyo B, Dachlan EG, Nasronudin. Hubungan antara Faktor Risiko Sepsis Obstetri dengan Kejadian Sepsis Berat dan Syok Sepsis di Departemen Obstetri dan Ginekologi, RSUD Dr. Soetomo, Surabaya. Maj Obstet Ginekol. 2010;20(Mei - Agustus):58-64.

4. Roeslani RD, Amir I, Nasrulloh MH. Penelitian Awal: Faktor Risiko pada Sepsis Neonatorum Awitan Dini. Sari Pediatr [Internet]. 2013;14(6):363-8. Available from: https://saripediatri.org/index.php/saripediatri/article/view/317.

5. Burlinson, Sirounis, KR W, Chau. Sepsis in pregnancy and the puerperium. Int J Obs Anesth. 2018;96107.

6. Albright, Mehta, Rouse, Hughes. Sepsis in Pregnancy: Identification and Management. J Perinat Neonatal Nurs. 2016;30(2):95-105.

7. Duarte, Danelli, Tavares, Morguette, Kerbauy, CMC G, et al. Fatal sepsis caused by mecA-positive oxacillin-susceptible Staphylococcus aureus: First report in a tertiary hospital of southern Brazil. J Infect Chemother. 2019;25(4):293-7.

8. Dillen V, Zwart, Schutte, Roosmalen V. Maternal sepsis: epidemiology, etiology and outcome. Curr Opin Infect Dis. 2010;23(3):249-54.

9. Acosta CD, Harrison DA, Rowan K, Lucas DN, Kurinczuk JJ, Knight M. Maternal morbidity and mortality from severe sepsis : a national cohort study. BMJ Open; 2016.

10. Suarjana IGK, Besung INK, Mahatmi H, PG KT. Modul Isolasi dan Identifikasi Bakteri. Fakultas Kedokteran Hewan Universitas Udayana; 2017.

11. Barton, Sibai. Severe sepsis and septic shock in pregnancy. Obs Gynecol. 2012;689-706. 